\title{
Combustion-derived nanoparticles: A review of their toxicology following inhalation exposure
} Ken Donaldson*1, Lang Tran², Luis Albert Jimenez ${ }^{1}$, Rodger Duffin ${ }^{1}$, David E Newby ${ }^{3}$, Nicholas Mills 3 , William MacNee ${ }^{1}$ and Vicki Stone ${ }^{4}$

\begin{abstract}
Address: ${ }^{1}$ ELEGI Colt Laboratory, Queens Medical Research Institute, University of Edinburgh, 47 Little France Crescent, Edinburgh EH16 4TJ, UK, 2Institute of Occupational Medicine, Research Park North, Riccarton, Edinburgh EH14 4AP, UK, ${ }^{3}$ Cardiovascular Research, Division of Medical and Radiological Sciences, The University of Edinburgh, Chancellor's Building, 49 Little France Crescent, Edinburgh EH16 4SU, UK and ${ }^{4}$ Napier University, School of Life Sciences, 10 Colinton Rd, Edinburgh EH10 5DT, UK
\end{abstract}

Email: Ken Donaldson* - ken.donaldson@ed.ac.uk; Lang Tran - Lang.Tran@iomhq.org.uk; Luis Albert Jimenez - a.jimenez@ed.ac.uk; Rodger Duffin - Rodger.Duffin@ed.ac.uk; David E Newby - d.e.newby@ed.ac.uk; Nicholas Mills - Nick.Mills@ed.ac.uk; William MacNee - wmacnee@ed.ac.uk; Vicki Stone - v.stone@napier.ac.uk

* Corresponding author

Published: 2I October 2005

Particle and Fibre Toxicology 2005, 2:10 doi:10.1186/1743-8977-2-10
Received: 18 April 2005

Accepted: 21 October 2005

This article is available from: http://www.particleandfibretoxicology.com/content/2/1/10

(c) 2005 Donaldson et al; licensee BioMed Central Ltd.

This is an Open Access article distributed under the terms of the Creative Commons Attribution License (http://creativecommons.org/licenses/by/2.0), which permits unrestricted use, distribution, and reproduction in any medium, provided the original work is properly cited.

\begin{abstract}
This review considers the molecular toxicology of combustion-derived nanoparticles (CDNP) following inhalation exposure. CDNP originate from a number of sources and in this review we consider diesel soot, welding fume, carbon black and coal fly ash. A substantial literature demonstrates that these pose a hazard to the lungs through their potential to cause oxidative stress, inflammation and cancer; they also have the potential to redistribute to other organs following pulmonary deposition. These different CDNP show considerable heterogeneity in composition and solubility, meaning that oxidative stress may originate from different components depending on the particle under consideration. Key CDNP-associated properties of large surface area and the presence of metals and organics all have the potential to produce oxidative stress. CDNP may also exert genotoxic effects, depending on their composition. CDNP and their components also have the potential to translocate to the brain and also the blood, and thereby reach other targets such as the cardiovascular system, spleen and liver. CDNP therefore can be seen as a group of particulate toxins unified by a common mechanism of injury and properties of translocation which have the potential to mediate a range of adverse effects in the lungs and other organs and warrant further research.
\end{abstract}

\section{Introduction}

Particulate matter (PM) is a complex mixture of different particle types, much of which are unlikely to cause any adverse effects and so the hypothesis has arisen that a subcomponent(s) of PM drives the adverse effects. Much research has been, and is being, undertaken to test various hypotheses regarding which of the components in fact drives adverse effects. Combustion has been recognised as a potential source of harmful particles as well as gaseous pollutants $[1,2]$. Epidemiological studies do not readily allow associations of adverse effects with sub-components of PM, dependent as they usually are on mass measures of PM. However several epidemiological studies have been able to identify combustion-derived particles as an important component in driving adverse effects of PM [3-7]. Toxicology can more readily study the components of PM 


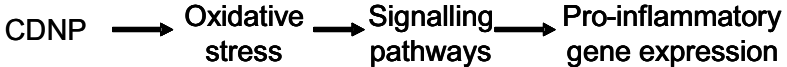

Figure I

and there has been considerable amount of research demonstrating the toxicity of combustion-derived particles such as diesel soot $[8,9]$, welding fume [10], carbon black [11] and nanoparticles coal fly-ash [12]. The workplace is also a site of exposure to combustion-derived nanoparticles as in the case of welding fume and in the manufacture of carbon black. We focus here on the toxicology of combustion-derived nanoparticles (CDNP) produced in a range of situations because reports on their mechanisms of toxicity suggest similarities.

CDNP present a diverse group of materials which gain commonality because of their origin in combustion processes and their demonstrated toxicity in various models. We have attempted to be systematic and have described the CDNP in terms of their physicochemistry then their adverse effects and finally their molecular toxicology; however there are gaps of various sizes in the available information and so we fall short of a truly systematic approach. We feel that this review is timely because the molecular toxicology of these materials is becoming better understood and the final common pathways of oxidative stress-mediated inflammation are now considered to underlie the effects of a range of CDNP. This is outlined in Figure 1 where the link between oxidative stress and inflammation is shown. In addition we review the evidence that CDNP and their components can migrate, from their site of deposition in the lungs, to other target organs.

\section{Combustion-derived nanoparticles}

Nanoparticles are defined as primary particles with at least one dimension $<100 \mathrm{~nm}$, while ultrafine particles are defined as particles $<100 \mathrm{~nm}$ in all dimensions (W Kreyling, personal communication) and are commonly produced by combustion processes $[1,2]$. Like other nanoparticles, CDNP agglomerate readily and move into the accumulation mode which decreases the particle number but probably leaves the surface area dose unaffected. NP have the ability to cause inflammation and also, in the case of insoluble CDNP, have potential to escape from the site of deposition in the lungs and translocate to the blood and to other target organs [13]. The exemplar CDNP discussed here (Table 1) include welding fume and nanoparticulate carbon black, which are both occupational hazards, coal fly-ash which is an environmental hazard and diesel soot which is both an environmental and an occupational hazard. CDNP are primary in the sense that they arise directly from the combustion process, although their chemistry may change with aging as the particles undergo chemical interactions with components of the ambient air pollution cloud. The process of burning concentrates metals, due to combustion and hence degradation of the organic fraction to a degree that is dependent on the efficiency of the combustion. At the same time pyrolysis chemistry generates other complex organic molecules, some of which may persist along with elemental carbon nanoparticles. Nanoparticles also form from atmospheric chemistry e.g. sulphate and nitrate nanoparticles but these will not be discussed here as they are not derived directly from combustion. The combustion materials and the mode of combustion will ultimately determine the characteristics of the CDNP, including chemical composition, particle size and particle solubility. The large surface area of CDNP presents maximal opportunity for dissolution of soluble species from the surface of the insoluble core. For insoluble NP, the large surface area provides a surface on which catalytic chemistry can occur that favours the formation of free radicals. These free radicals are responsible for driving oxidative stress, the underlying mechanism that promotes an inflammatory response to CDNP. For a range of low toxicity, low solubility particle types the surface area alone is the driver for lung inflammation following instillation in rats [14]. CDNP may be soluble and release transition metals or organics as their primary pro-inflammatory mechanism. Both transition metals and organics can undergo complex cyclical chemical reactions in the milieu of the lungs that lead to the production of free radicals such as superoxide anion or hydroxyl radical [15-17]. By contrast low toxicity insoluble particles cause inflammation because of their surfaces; some types of CDNP have both soluble components and an insoluble core.

As detailed in this review, exposure to CDNP of various types is associated with a range of adverse health effects including fibrosis, chronic inflammatory lung disease, metal fume fever and cancer. These endpoints are found across a number of exposure conditions and to different kinds of CDNP but are not unique for CDNP.

This paper examines the evidence for harmful effects of CDNP and puts these in the context of a unifying hypothesis based on observations that the generic ability of CDNPs to cause inflammation is via oxidative stress and activation of redox-sensitive transcription factors that can lead to the adverse health effects listed below. The ability of CDNP and their associated metals to translocate to the blood and the brain are also discussed. These unusual 
Table I: Characteristics of the CDNP considered in this review

\begin{tabular}{|c|c|c|c|}
\hline \multirow[t]{2}{*}{ CDNP } & \multirow[t]{2}{*}{ Origin } & \multicolumn{2}{|c|}{ Reported health effects } \\
\hline & & animals & humans \\
\hline Diesel exhaust particles & Combustion of diesel oil & Inflammation, fibrosis, cancer, & Inflammation, cancer? \\
\hline Welding fume & Welding processes & $\begin{array}{l}\text { Inflammation; translocation of metals to } \\
\text { the brain }\end{array}$ & $\begin{array}{l}\text { Metal fume fever, fibrosis, cancer, } \\
\text { bronchitis }\end{array}$ \\
\hline Fly-ash & Combustion of coal or oil & inflammation & no data available \\
\hline NP Carbon black & Combustion of heavy fuel oil & $\begin{array}{l}\text { Inflammation, lung cancer; translocation of } \\
\text { particles to the brain }\end{array}$ & no data available \\
\hline
\end{tabular}

toxic properties unite these materials and suggest that they can usefully be seen as a group of particulate lung toxins that act through similar pathways.

\section{Health effects associated with exposure to CDNP}

CDNP are generated in a number of scenarios including internal combustion engines, large scale burning of coal for power generation and in industrial processes where they often could be produced along with larger particles. The CDNP considered here are described in Table 1 along with their salient effects in humans and animals.

\section{Diesel exhaust particulate}

Both petrol and diesel fuels undergo combustion in automobile engines and give rise to CDNP $[18,19]$ but diesel produces more particles per unit fuel than petrol and is by far the most-studied of the two regarding adverse health effects; therefore diesel CDNP are discussed here. Diesel fuel is a middle distillate of petroleum which contains paraffins, alkenes and aromatics[20]. On combustion in automobile engines it produces low solubility carboncentred nanoparticles with complex chemical and physical structure, containing sulphates and an organic fraction comprising unburnt fuel, lubricating oil and polycyclic aromatic hydrocarbons along with a range of other chemicals, which can condense on the particles [20,21]. Singlet Diesel nanoparticles are 5-20 nm but readily form complexes chains and aggregates of 60 to $100 \mathrm{~nm}$ and larger [22]. Diesel exhaust particles (DEP) are usually the most common CDNP in urban environmental air and in environmental particulate air pollution $\left(\mathrm{PM}_{10}\right)$ in conurbations generally; they also occur in an occupational setting. In the ambient environment the concentration of DEP in $\mathrm{PM}_{10}$ is likely to range from $5-30 \mu \mathrm{g} / \mathrm{m}^{3}$ while in occupational settings levels up to $1000 \mu \mathrm{g} / \mathrm{m}^{3}$ have been experienced [20]. The adverse health effects of exposure to DEP have been extensively studied epidemiologically, in animals and in cells. Epidemiological studies have been reviewed and show that there is a strong link between occupational exposure to diesel soot and lung cancer [20].
Animal studies generally support these findings and demonstrate that exposure to DEP and other nanoparticulate forms of carbon are carcinogenic [23] but these findings are complicated by the issue of rat lung overload [24]. Rat lung overload is a condition when very high lung surface area burden [25] of low toxicity, low soluble particles leads to failure of clearance, rapid accumulation of dose with concomitant inflammation and proliferation, which culminates in fibrosis and cancer. Humans are unlikely to experience overload levels of diesel soot, even in occupational settings, and there is a question over whether overload can occur at all in humans. It is therefore unlikely that cancer associated with DEP-exposure in humans results from mechanism similar to rat lung overload. Exposure to DEP has also been shown to be highly inflammatory in rats and mice in non-overload conditions [26-28] and to induce pro inflammatory effects on cells in vitro [29-31]. The well-documented link between inflammation and lung cancer [32-34] supports the idea that diesel exhaust may indeed be carcinogenic via an inflammatory pathway (see below).

Many studies have demonstrated profound adjuvant effects of diesel particles on development and intensity of allergic responses and these effects are mediated by direct effects of DEP on a wide range of cell types involved in allergy [35]. These effects could also be mediated indirectly through inflammation and oxidative stress [35]. The inflammatory effects of DEP appear to be driven by the particulate component i.e. the surface area effect [23] although the organic [36] and metal components [37] also appear to play a role in oxidative and pro-inflammatory effects and thereby affect pathogenicity.

\section{Welding fume}

Welding is an industrial technique that involves the joining of metal pieces using a filler metal. The filler metal is produced from an electrode wire that is consumed during the welding fusion process. High temperatures are involved, generating a welding fume as well as radiation, noise and gases [38] but we focus her on the fume parti- 
cles. The vaporized metal produced by the heat of the welding process oxidises to produce a fume containing particles of metal oxide such as aluminium, cadmium, chromium, and copper [38], many of which are water soluble. The exact composition of the welding fume is determined by the metals involved in the weld and the composition of the electrode. Welding fume particles are comprised of a large proportion of nanoparticles [10].

Exposure to welding fume has been associated with both pulmonary and systemic health endpoints reviewed in [38]. These include decreases in pulmonary function, increased airway responsiveness, bronchitis, fibrosis, lung cancer and increased incidence of respiratory infection; in addition to these pulmonary effects metal fume fever is frequently observed in welders $[38,39]$. This systemic condition is considered to be caused by inhalation of zinc oxide fumes and it is characterised by acute onset of a flulike illness accompanied by a dry cough, dyspnea, muscle aches, headaches and fever [40]. Metal fume fever is usually experienced in the first periods of exposure and on Mondays, with the symptoms declining as the working week progresses. Welding fume has been studied in both animals and in cells in culture, and in both it produces marked pro-inflammatory effects $[10,41,42]$. These effects are driven largely by the transition metals $[10,42,43]$ which undergo redox-cycling resulting in oxidative stress.

\section{Nanoparticulate carbon black}

Carbon black (CB) is a low solubility particle produced industrially from incomplete thermal decomposition of hydrocarbons [44] in which the process is controlled to achieve pre-defined and reproducible particle sizes and properties suitable for a diverse range of industrial applications. Unlike the other CDNP described here NPCB is not accidentally produced, and is an industrial product but it clearly classifies as a CDNP. In thermal-oxidative processes such as the furnace black process, various types of hydrocarbon are sprayed into a natural gas-fired furnace and quenched with water to prevent complete burning [45]. The carbon black particles so-formed are complex, with a degenerated graphitic crystallite structure and high power electron micrographs clearly show irregular layered graphitic plates. [44]. The structure of carbon black is described as nodules, the roughly spherical primary structural elements, aggregates which comprise fused, connected particles and agglomerates, which are undispersed clusters of aggregates. CB has been studied extensively as to its toxicology, especially as an example of a low toxicity, low solubility particle not complicated by harmful levels of toxicologically-relevant organics or metals [23]. In long-term animal studies CB was found to be a carcinogen although rat lung overload very likely plays a role in this affect [46].
The smallest nodule-or particle-sized $\mathrm{CB}$ comprises primary particles in the low tens of nanonetres size range. $\mathrm{CB}$ with smallest primary particle sizes produces the highest optical density (jetness) compared to larger particle sizes, placing this material in demand for colouring enamels, acrylics and plastics, as well as inks and paints [44]. This nanoparticulate CB (NPCB), as it has come to be known, comprises a portion of the overall CB industry. NPCB was able to cause detectable but low level pro-inflammatory effects in rats following 7 hours inhalation exposure [47] and also following instillation [11] and this appears to be a consequence of the high surface area area per unit mass [14]. In cell studies NPCB has been shown to cause oxidative stress, pro-inflammatory gene transcription [48] stimulation of phagocytosis at low doses and inhibition at higher doses [49]. In studies of the health status of individuals working in the carbon black industry there is evidence of abnormalities in chest radiographs and respiratory morbidity, but equivocal findings on lung cancer [50-52]. However, none of these studies analysed a worker population exposed solely to NPCB. NPCB has been used quite extensively in particle toxicology as a model particle and nanoparticles, so there is a considerable existing database on its toxicity in vitro and in vivo [53].

\section{Coal fly ash}

Pulverised coal combustion is a commonly-used and efficient method of coal burning in power stations. In pulverized coal power stations the pulverised coal is blown into the furnace and burned off producing a fly ash emission. This particulate emission is controlled by number or methodologies including electrostatic precipitators, filters scrubbers and mechanical collectors [12]. However, these control measures are not $100 \%$ effective and some particles are released into the environment.

Toxicology studies have in general examined unfractionated pulverised coal fly ash (CFA) and these have shown generally low toxicity [54], however bioavailable iron has been reported to underlie an ability to generate oxidative stress $[55,56]$. Coal fly ash-exposed rats have been shown to exhibit increased susceptibility to infection [57], while a specially-prepared cloud of ultrafine (nanoparticulate) coal fly ash induced adverse effects on guinea pig lung function [58]. A recent study systematically examined the effect of fractionated coal fly ash in pulmonary inflammation and a nanoparticle fraction was available [12]. This study showed greatly enhanced potency of the nanoparticulate fraction compared to the fine and coarse fractions, as seen by enhanced ability to cause lung inflammation and kill macrophages in culture. The nanoparticle fraction was not especially enriched for toxic metals and the increased toxicity of this fraction may be a result of the high surface area, allowing redox reactions to take place. 


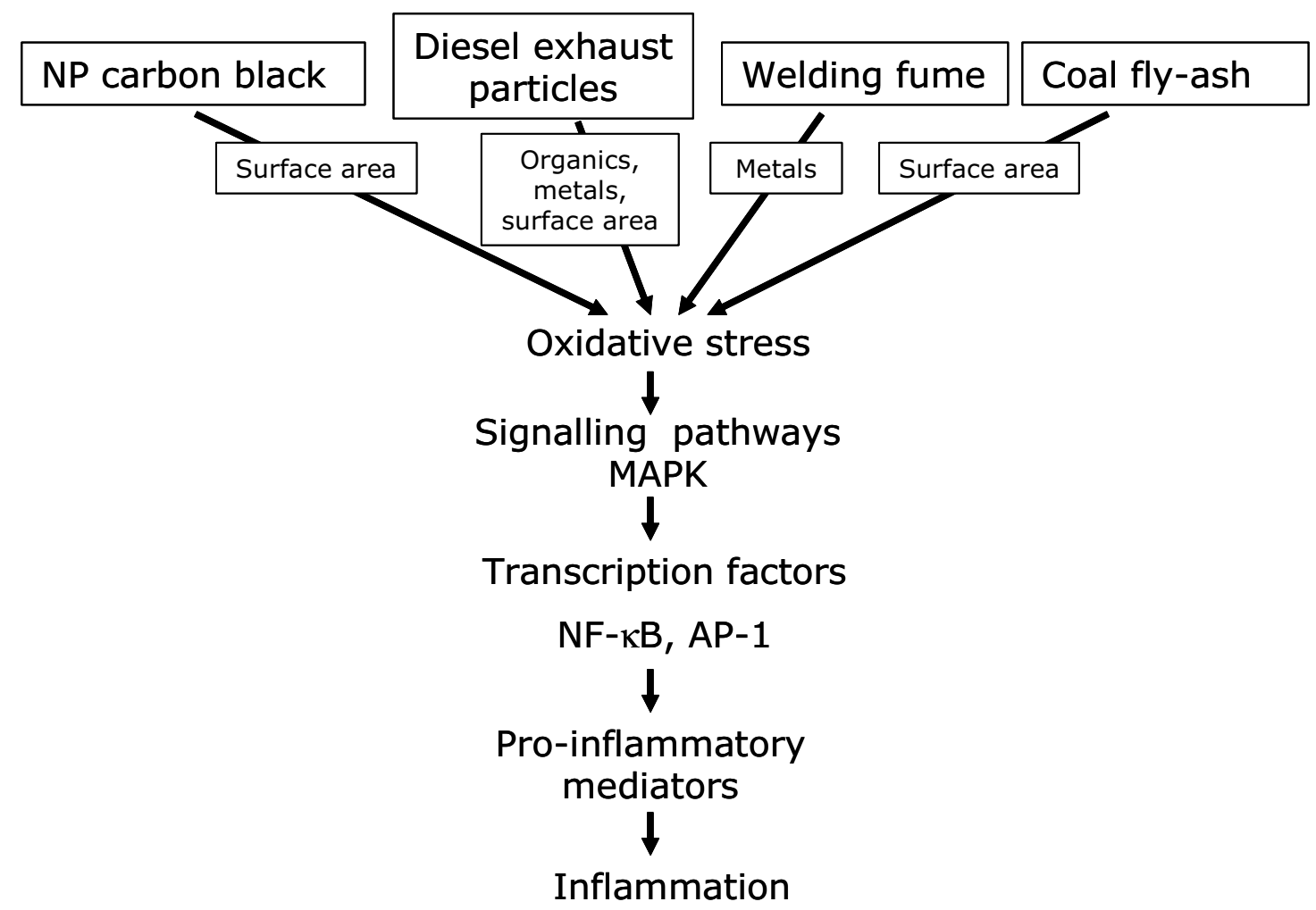

Figure 2

\section{Molecular toxicology mechanisms driving the inflammatory effects of CDNP in lungs}

Based on published studies we hypothesise that CDNP have their effects through common pathways that produce inflammation and that oxidative stress is the lead effect driving the adverse health effects. Table 1 shows the CDNP studied in this paper along with a description of their origin and reported health effects in animals and humans.

There is considerable mechanistic data describing the molecular events flowing from the deposition in the lungs of the different CDNP under discussion here and this is outlined in Figure 2. Figure 2 shows that different components of different CDNP can cause oxidative stress that acts through well-documented redox-sensitive pathways, such as MAPK and NF- $\kappa \mathrm{B}$, to cause inflammation. Although the components that mediate these effects differ greatly between the different CDNP, there is commonality through their ability to cause oxidative stress and inflammation.

\section{Diesel exhaust particles}

As described above DEP causes inflammation in rat lungs $[28,59]$ and in human lungs [60] following short-term, high level exposure. Evidence of the oxidative properties of DEP in vivo is shown by increased level of $8 \mathrm{OH} \mathrm{dG}$, the oxidative adduct of hydroxyl radical, in the lungs of rats following exposure and in cells in culture treated with DEP $[61,62]$. DEP causes oxidative stress in a number of models in vitro such as oxidation of low density lipoprotein (LDL) [63] and in exposed epithelial cells [9,64]. The component responsible for the oxidative stress and subsequent pro-inflammatory signaling is principally the organic fraction $[9,30,64,65]$, although transition metals may also be involved $[37,66]$. The organic fraction either contains, or can be metabolized to, species such as qui- 
nones that can redox cycle in cells to generate reactive oxygen species [17]

Activation of signaling pathways for pro-inflammatory gene expression is seen in a number of studies using DEP; these include MAPK activation [30,67-69] and NF- KB activation $[30,70]$. As would be anticipated, activation of these pathways culminates in transcription of a number of pro-inflammatory genes such as IL-8 in epithelial cells treated in vitro [71] and in human lungs exposed by inhalation [72]. TNFa has been reported to be increased in macrophages exposed to DEP in vitro [73] and IL-6 is released by primed human bronchial epithelial cells exposed to DEP [74]. Increased expression of the GM-CSF gene is reported in human epithelial cells exposed to DEP; in humans exposed to short-term high levels of DEP similar to those encountered in a busy garage, bronchial biopsies showed increased GRO $\alpha$ and RANTES expression in the bronchial wall [75].

\section{Nanoparticulate Carbon black (NPCB)}

As described previously, at high exposures carbon black causes overload tumours in rats $[27,46]$. NPCB causes inflammation and the onset of rat lung overload tumours at a lower lung mass burden than larger, respirable CB [76]. This reflects the reliance of rat lung overload on the particle surface area burden [25], which is much greater for a given mass of NPCB than the same mass of non-NP respirable CB. Even at low lung burden NPCB showed evidence of mild pro-inflammatory effects whilst respirable CB did not [47]. Similar greater inflammogenicity of NPCB than respirable CB has been described with instillation models, [11,77].

Reactive oxygen species production has been measured with NPCB using in vitro cell-free systems $[78,79]$ and oxidative stress has been demonstrated in exposed cells $[48,80]$. The chemical basis of the ability of NPCB to cause oxidative stress [78] is unknown, but unlike highly soluble welding fume, ROS production is not related to metal or any other soluble component [77]. In a cell free system the NPCB particles and similarly polystyrene NP, induce ROS production [81], suggesting that the surface reactivity is sufficient. However, in cells this ability may also be related to increased influx of extracellular $\mathrm{Ca}^{++}$ions seen with NPCB [82]. Oxidative stress raises intracellular calcium by increasing release of $\mathrm{Ca}^{2+}$ from the endoplasmic reticulum, by enhancing ingress of $\mathrm{Ca}^{2+}$ through the plasma membrane calcium channels and through inhibition of $\mathrm{Ca}^{2+}$ transport out through the ATPase pumps in the plasma membrane [83]. Oxidative stress caused by NPCB is translated into activation of NF- $\mathrm{KB}$ and IL- 8 gene expression in epithelial cells in vitro [48], while both oxidative stress and calcium are implicated in activation of AP-1 and TNF $\alpha$ production in macrophages [84]. A recent study reports that NPCB causes oxidative stress-mediated proliferation of airway epithelium, involving the Epidermal Growth Factor Receptor and the ERK cascade [85].

\section{Welding fume}

Exposure to welding fume nanoparticulate in humans is associated with inflammatory cytokine increases in the bronchoalveolar lavage (BAL) [86-88] and systemic oxidative stress [43]. The ability of welding fume to generate free radical is abundantly clear, even in a cell-free environment with only $\mathrm{H}_{2} \mathrm{O}_{2}$ acting as a reductant [42]. Rats exposed to welding fume show marked pulmonary inflammatory responses $[42,89,90]$ and lipid peroxidation indicative of oxidative stress [42]. In a comprehensive study of the molecular signaling pathways leading to inflammation with welding fume, McNeilly et al demonstrated that the pro-inflammatory effects of welding fume in vitro [10] and in vivo [91] were entirely driven by oxidative stress arising from the soluble transition metal component. Epithelial cells treated with welding fume or the soluble transition metals from them showed oxidative stress leading to MAPK-dependent (manuscript in preparation) NF- $\mathrm{KB}$ and AP-1 activation leading to IL-8 gene transcription [10]. For welding fume nanoparticles, therefore, the soluble transition metals appear to be the primary mechanism of oxidative stress and inflammation.

\section{Coal fly ash}

In the past coal fly ash has been shown to have relatively low toxicity, for example lower than coal or quartz [54]. Recently there has been increasing interest in the ability of CFA to release bioavailable iron which can redox cycle to produce oxidants $[55,92]$. One study showed that the ability of a CFA standard to induce IL-8 release from epithelial cells was dependent on size, with the smallest size fraction $(<1 \mu \mathrm{m})$ containing the most IL-8-stimulating activity [92]; this was due to the fact that the bioavailable iron was concentrated in this fraction. There was no attempt in this study to collect a nanoparticle fraction. In a study especially relevant to our review of CDNP, Gilmour et al [12] demonstrated that the nanoparticulate fraction of sub-bituminous coal was much more potent than any other fraction in causing lung inflammation and cytotoxicity in vitro, when compared on a mass basis. This was not obviously linked to enrichment of Fe or any other toxic metals in the nanoparticulate fraction. Electron microscopic examination of the nanoparticulate fraction of coal fly-ashes from bituminous and low-rank coals showed abundant discrete crystalline particles rich in $\mathrm{Fe}$, $\mathrm{Ti}$, and $\mathrm{Al}$ crystalline phases down to $10 \mathrm{~nm}$ in size whilst low-rank samples contained considerable amounts of alkaline-earth element aggregates in the form of phosphates, silicates, and sulfates and mixed species. Importantly, all coal fly-ash samples exhibited carbonaceous particles in the form of soot aggregates with primary 
particle size typically between 20 and $50 \mathrm{~nm}$ sometimes mixed or coated with multi-element inorganic species [93]. It seems possible that the soot particles were an important component in driving the adverse effects in ways analogous to the effects of diesel soot and NPCB.

There are no further studies on the ability of the NP fraction of CFA to cause oxidative stress or signal for inflammatory gene expression but such studies are warranted and we would predict that, along with the other CDNP discussed here, the pathway shown in Figure 2 would be activated, leading to inflammation.

\section{CDNP and the cardiovascular system}

Large scale epidemiological studies suggest that inhaled ambient air pollution particles $\left(\mathrm{PM}_{10}\right)$ may also have effects on the cardiovascular system. Small increases in particulate levels are associated with more cardiovascular deaths and hospital admissions in both time-series $[94,95]$ and population studies [96,97]. Cohort studies have documented an association between elevated particulate and the onset of acute myocardial infarction $[98,99]$, an increase in heart rate [100] and a decrease in heart rate variability [101]. Human chamber studies delivering concentrated ambient particles (CAPs) have confirmed that particulate can have direct effects on cardiovascular physiology with alterations in heart rate variability [101] and brachial artery diameter [102].

This CAPS work has not been able to discriminate which size fraction is responsible for any effects but the hypotheses relating to cardiovascular effects of CAPS (and PM in general) are as follows 1) particle-induced lung inflammation affects the endothelium, thrombotic potential, fibrinolytic balance and atheromatous plaque activity in ways that favour plaque rupture and thrombosis; 2) particles enter the interstitium and/or cause inflammation which affects the autonomic nerve endings that regulate the heart rhythm leading to dysrhythmia; 3) particles translocate to the blood and have direct effects on the endothelium, plaques and thrombogenic mechanism. In various models NP are shown to be highly potent in these three areas of effect i.e. NP are very potent at causing inflammation, they interstitialise readily and they can gain access to the blood. For these reasons CDNP, the principal NP in ambient air, are implicated in the cardiovascular effects of PM in these CAPS studies.

These studies address the population risks associated with ambient particulate, but do not allow any assessment of the contribution of individual air pollutants. In the Copenhagen Male Study the influence of occupational exposure on cardiovascular risk was assessed. In these men, 5 years or more of occupational exposure to welding fumes doubled the risk of myocardial infarction with exposure to solder and plastic fumes conferring similar increases in risk [103].

Figure 3 shows the two predominant mechanistic pathways hypothesised to mediate the adverse cardiovascular effects of CDNP $[104,105]$. On the right of Figure 3 inflammation caused by the CDNP is seen to affect the systemic inflammatory response and cause destabilisation of atheromatous plaques. On the left, bloodborne CDNP affect endothelial cells, platelets and plaques directly to enhance thrombogenesis.

CDNP are capable of eliciting an inflammatory response in the lung which could have stimulatory effects on leukocytes and other cells in the atherosclerotic plaques, leading to their rupture. This could occur is in the absence of any transfer of CDNP from the lungs to the circulation as it might rely on cytokines and other mediators which were released into the circulation in response to events in the lungs, affecting events in the plaques. However, CDNP could also have effects on the cardiovascular system by virtue of their ability to gain access to the bloodstream. This has been demonstrated in animal studies for a range of nanoparticles delivered by inhalation and instillation [106-111]. Once circulating, CDNP may interact with the vascular endothelium, or have direct effects on atherosclerotic plaques by entering them and causing local oxidative stress and pro-inflammatory effects similar to those caused in the lungs. Increased inflammation could destabilise the coronary plaque, resulting in rupture, thrombosis and acute coronary syndrome [104]. Furthermore, particles may interact with circulating coagulation factors to promote thrombogenesis. There is, as yet no published data demonstrating that the CDNP described here gain access to the blood in humans, but the animal studies suggest that this is a plausible hypothesis.

\section{CDNP and the brain}

Recent work by Oberdorster and colleagues has demonstrated the transfer of radiolabelled nanoparticulate carbon from the nose of rats directly into the brain [112]. It is postulated that this transfer occurs via the olfactory nerves which run from the roof of the nasal cavity in to the olfactory lobes of the brain. However, this part of the brain is well vascularised, providing a potential systemic portal of deposition. If size is the factor that drives these effects then there is some concern that CDNP may have the general property of tropism to the brain. A search of relevant terms showed no published studies pertaining to brain transfer of diesel or coal fly-ash. The best-studied of the CDNP in regard to brain transfer is welding fume. Rats exposed to stainless steel welding fume over 60 days showed accumulation of manganese in the blood and liver but, most importantly, also in various areas of the brain [113]. Erikson et al [114] showed that inhalation 


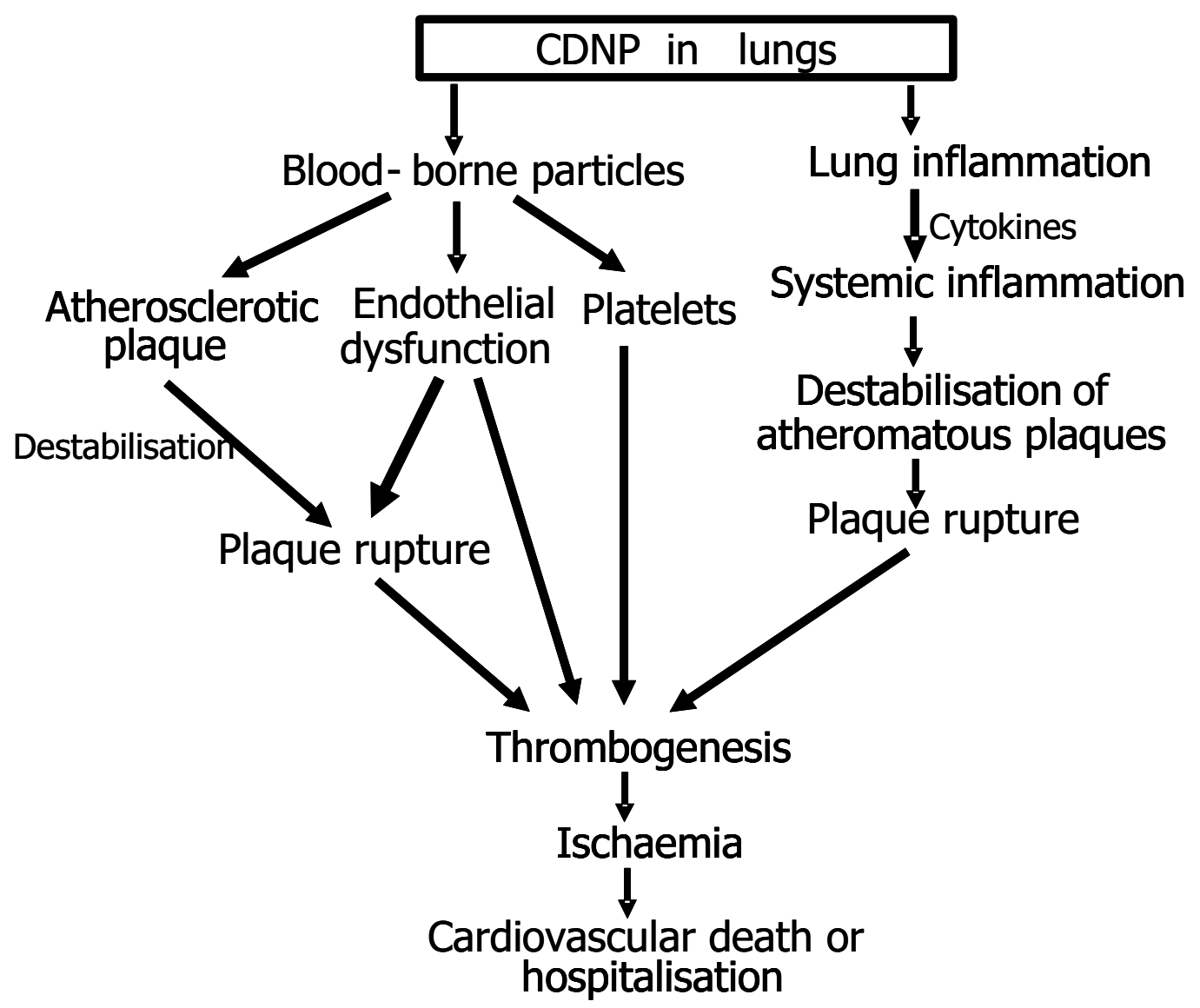

Figure 3

exposure to manganese sulphate and manganese phosphate produced oxidative stress in the brains of rats as shown by metallothienin and glutamine synthetase levels; this varied between sexes and with age. In a subchronic exposure study with manganese phosphate there was accumulation of $\mathrm{Mn}$ in the brain but there was no associated loss of neurons or neurobehavioural effects [115]. Studies of workers exposed to welding fume, however, show clear evidence of neurological disease [116] and $\mathrm{Mn}$ is implicated in these effects [117]. It is not known whether the welding fume particles themselves are transferred to the brain or only the soluble $\mathrm{Mn}$ and other metals. However, soluble metals are very rapidly lost from welding fume particles [10] and a soluble salt of Mn was more efficient than an insoluble $\mathrm{Mn}$ salt in gaining access to the brain following inhalation exposure in rats [118]. Further work is required to improve our understanding of the factors dictating the transfer of CDNP and their associated soluble contaminants to the brain.

\section{CDNP and the liver and spleen}

As discussed above, NP of various types are reported to gain access to the blood. Stuart showed in 1970 that the liver and the spleen turn black following the instillation of carbon particle into the blood because the spleen and the liver have sinusoidal phagocytes which are in contact with the blood - the 'littoral' macrophages [119]. There is existing evidence that particles can gain access to the blood since coalworkers, who receive considerable exposure to particles, show greater numbers of particles in their 
spleen and liver at autopsy than non-coalworkers [120]. The amount of particulate in the spleen and liver, which can be assumed to have travelled via the blood, was greater in coalworkers with more severe lung disease, suggesting that inflamed/damaged lungs may be more susceptible to egress of particles into the blood than normal lungs. The normal function of the littoral macrophages of the spleen and liver is probably to 'sample' for antigens and xenobiotics in the blood and to quickly remove any bacteria that gain access to the blood. We may therefore anticipate that any NP that gain access to the blood will be taken up by these littoral macrophages in the spleen and the liver. Particles may also reach hepatocytes and other spleen cells with consequences that are presently unknown. However, in line with the above arguments pertaining to the potential role of NP in the adverse effects of $\mathrm{PM}_{10}$, we may anticipate that increases in acute phase proteins during periods of high PM [121] could be due to direct particle effects on the liver, the primary source of acute phase proteins [122]. In the single study that has so far been published concerning the effects of bloodborne NP on liver function of healthy mice, CDNPs induce platelet accumulation in the hepatic microvasculature that was associated with pro-thrombotic changes on the endothelial surface of hepatic microvessels. [123]. The accumulation of particles in the liver exerted a strong procoagulatory effect but did not trigger an inflammatory reaction. The effects of a particle burden on the spleen are unknown but could include adjuvant effects as observed with diesel particles and antigens in the lung [124].

\section{CDNP and genotoxicity}

The genotoxic properties of various particle types has been the focus of several studies concerned with elucidating the role such properties play in particle-associated pathogenicity [34]. However, the mechanisms involved in particle-induced genotoxicity remain poorly understood as particles are uniquely complex compared with soluble genotoxic/carcinogenic compounds, due to their physical and chemical characteristics [125]. There is evidence that 3 of the 4 CDNP studied in this review (diesel, NPCB and welding fume) are carcinogenic in humans or rats $[20,38,126,127]$. As mentioned earlier, DEP consist of a carbon core with adsorbed PAHs, quinones and transition metals. Genotoxicity, may therefore be caused by the direct (primary) interaction of PAHs which are known to cause DNA adduct formation [128] or alternatively via DNA strand breakage due to the production of reactive oxygen species generated by associated transition metals [8]. Carbon black particles are generally almost free of adsorbed organic compounds; however they have been shown to produce lung tumours in rats following chronic inhalation and instillation studies $[127,129]$. This indirect (secondary) genotoxicity pathway involves the phenomenon of lung particle overload resulting in a chronic

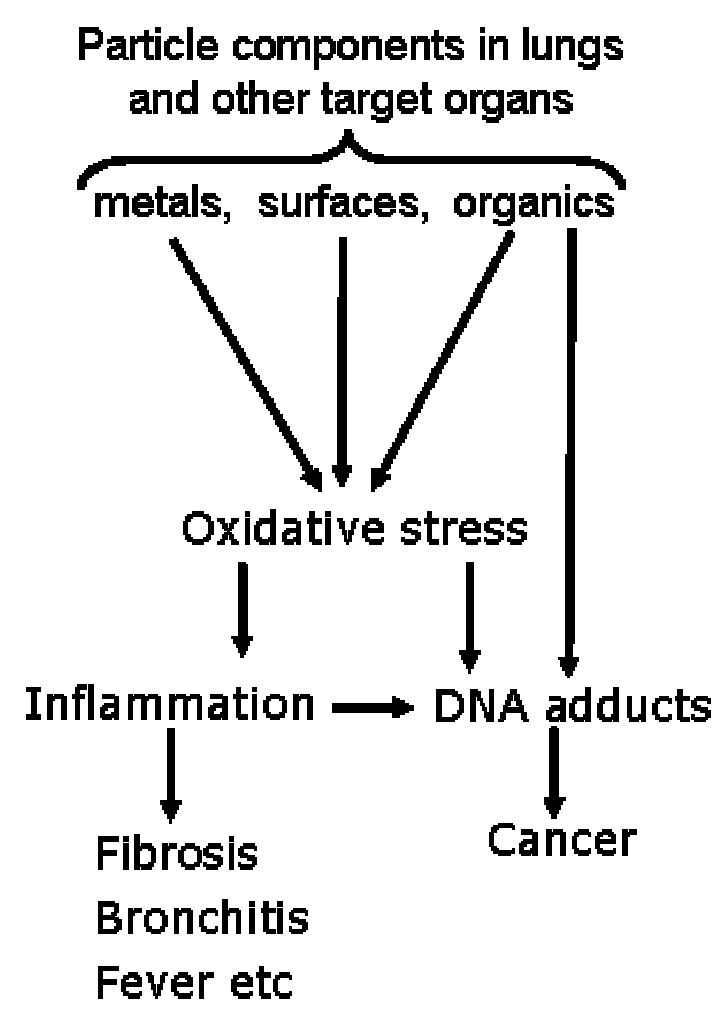

Figure 4

inflammation and hence excessive ROS production leading to DNA damage. Studies by Knaapen et al, have demonstrated that co-incubation of rat lung epithelial cells with activated neutrophils in vitro stimulate the formation of the oxidative DNA lesion 8-OH-dG [32]. Less research has been carried out on the genotoxic effects of welding fumes. Some of the major components of welding fumes include iron, manganese, chromium and in particular hexavalent chromium $\left(\mathrm{Cr}^{\mathrm{VI}}\right)$ chromium which has been shown to increase levels of 8-OH-dG in rats after inhalation exposure [130]. Yu and co-workers showed that rats exposed for 30 days to manual metal arc stainless steel (MMA-SS) welding fumes, exhibited increased DNA damage as measured by the comet assay and immunohistochemistry for 8-OH-dG [131]. Studies investigating the genotoxic capacity of coal fly ash have shown a role for particulate size and iron release leading to radical generation and oxidative DNA damage $[132,133]$ as well as increased sister-chromatid exchange (SCE) frequencies in peripheral blood lymphocytes from workers occupationally exposed to coal fly ash [134]. 


\section{Conclusion}

Combustion is considered a source of toxic chemicals and particles [1] and this review has focused solely on the toxicology of the particulate component. Emanating, as they do, from very diverse combustion scenarios, CDNP have received variable and piecemeal research attention. This review has used diesel soot, welding fume, carbon black and fly-ash as exemplar CDNP to demonstrate that different CDNP in fact have many properties in common that suggest that they can be viewed as a coherent class of particulate toxins. They are unified by their combustion origin, small size, universal mechanism of injury and common properties of translocation which have the potential to mediate a range of adverse effects in the lungs and other organs. Notably, the CDNP studied here all have the potential to cause oxidative stress as an integral part of their pathogenic mechanism. This oxidative stress can cause inflammation and its local and systemic acute and chronic sequelae, as well as causing oxidative adducts in epithelium that can contribute to carcinogenesis. CDNP originating from any source can therefore be considered a potential hazard to the lungs and other systems through the pathways of oxidative stress, inflammation and carcinogenesis. This is summarised in Figure 4 where the link between oxidative stress and inflammationrelated effects are shown along with carcinogenic effects of oxidative stress.

Of course the temperature, conditions and substrate for combustion mean that there is considerable heterogeneity in composition between, for example, welding fume and diesel soot. Therefore the key oxidative stress event may originate from different components depending on the particle under consideration. Components that may cause oxidative stress include CDNP-associated surfaces, metals or organics; this oxidative stress then acts through oxidative stress-responsive signalling pathways to affect responses such as inflammation and proliferation. In addition, oxidative stress can also cause oxidative genotoxic DNA adducts such as 8-OH-dG whilst bulky PAHderived adducts may also form. Both adduct types can lead to mutation. Different components of CDNP may interact to enhance the level of oxidative stress, as in the case of metals and organics interacting in the redoxcycling of quinoid organics [17] or CDNP surfaces and transition metals interacting additively in their ability to cause inflammation [81].

In addition to the local inflammatory effects of CDNP at their sites of deposition they have the potential to translocate away from their site of deposition to the blood and brain. Bloodborne particles will be delivered to the cardiovascular system, spleen and liver. The cardiovascular system has emerged as a target for the effects of $\mathrm{PM}_{10}[104$, 135] and it is likely that the CDNP in PM in fact mediate this effect [3-6]. They may do this through causing inflammation in the lungs which then impacts on inflammatory processes in the atheromatous plaques that govern their stability and development. Inflammation in the lungs may also affect the thrombotic potential of the blood. Alternatively, direct effects of bloodborne particles on the endothelium, clotting system and on atheromatous plaques could be responsible. Bloodborne CDNP may deposit in the spleen, liver and heart and in these situations they may have numerous additional adverse effects.

Combustion is a ubiquitous in the modern world and the generation of CDNP is correspondingly omnipresent. Much research emphasis has been placed on trafficderived CDNP in PM and rightly so as they are the source of most CDNP in our cities where the greatest potential for human exposure exists. However it is also clear that there is considerable potential for mixed exposures to occur in specific scenarios, e.g. a welder working in a busy street. The interactions between different particle types are unknown but the common pathway of oxidative stress means that there is potential for additive or synergistic effects. Furthermore the involvement of oxidative stress in a number of chronic diseases such as asthma, COPD and coronary artery disease argues a powerful case for existence of susceptible populations, already well-studied in the adverse effects of PM.

CDNP represent an interesting and ubiquitous category of pathogenic particles whose adverse effects are substantial and additions to the list of candidate CDNP are to be anticipated. More research is warranted into the effects of CDNP at numerous levels from factors dictating their translocation between organs and tissue to their effect in sub-cellular signalling. Viewing CDNP as a class of particles with common origins and a strong hypothesis-based understanding of their toxic mechanisms should provide impetus and direction to research on existing and new CDNP, leading to a greater understanding.

\section{Competing interests}

The author(s) declare that they have no competing interests.

\section{Authors' contributions}

KD planned the study and contributed to all the sections; LT contributed to all of the sections; LAJ contributed to all of the sections except the cardiovascular section; RD wrote the section ongenotoxicity and contributed to the other sections; DN and NM wrote the section on cardiovascular effects and contributed to all of the sections; WMacN contributed to all of the sections; VS contributed to the planning of the paper and contributed to all of the sections. 


\section{References}

I. Avakian MD, Dellinger B, Fiedler H, Gullet B, Koshland C, Marklund S, Oberdorster G, Safe S, Sarofim A, Smith KR, Schwartz D, Suk WA: The origin, fate, and health effects of combustion by-products: a research framework. Environ Health Perspect 2002, I | 0: I | 55- I | 62.

2. Lighty JS, Veranth JM, Sarofim AF: Combustion aerosols: factors governing their size and composition and implications to human health. J Air Waste Manag Assoc 2000, 50: I565-1618.

3. Pope CAIII, Hill RW, Villegas GM: Particulate air pollution and daily mortality on Utah's Wasatch Front 2. Environ Health Perspect 1999, I07:567-573.

4. Laden F, Neas LM, Dockery DW, Schwartz J: Association of fine particulate matter from different sources with daily mortality in six U.S. cities. Environ Health Perspect 2000, 108:94I-947.

5. Schwartz J: What are people dying of on high air-pollution days. ENVIRONMENTAL RESEARCH 1994, 64:26-35.

6. Ibald-Mulli A, Wichmann HE, Kreyling W, Peters A: Epidemiological evidence on health effects of ultrafine particles. J Aerosol Med 2002, I5:189-201.

7. Wichmann HE, Peters A: Epidemiological evidence of the effects of ultrafine particle exposure. Phil Trans $R$ Soc Lond $A$ 2000, 358:2563-2565.

8. Dybdahl M, Risom L, Bornholdt J, Autrup H, Loft S, Wallin H: Inflammatory and genotoxic effects of diesel particles in vitro and in vivo I. Mutat Res 2004, 562:I19-131.

9. Hirano S, Furuyama A, Koike E, Kobayashi T: Oxidative-stress potency of organic extracts of diesel exhaust and urban fine particles in rat heart microvessel endothelial cells. Toxicology 2003, 187:161-170.

10. McNeilly JD, Heal MR, Beverland IJ, Howe A, Gibson MD, Hibbs LR, MacNee W, Donaldson K: Soluble transition metals cause the pro-inflammatory effects of welding fumes in vitro. Toxicol Appl Pharmacol 2004, 196:95-107.

II. Renwick LC, Brown D, Clouter A, Donaldson K: Increased inflammation and altered macrophage chemotactic responses caused by two ultrafine particle types. Occup Environ Med 2004, 6 I:442-447.

12. Gilmour MI, O'Connor S, Dick CA, Miller CA, Linak WP: Differential pulmonary inflammation and in vitro cytotoxicity of sizefractionated fly ash particles from pulverized coal combustion. J Air Waste Manag Assoc 2004, 54:286-295.

13. K D, V S, Tran CL, W K, PJA B: Nanotoxicology: a new frontier in particle toxicology relevant to both the workplace and general environment and to consumer safety. Occup Environ Med 2004, in press:.

14. R D, A C, DM B, Tran CL, W MN, V S, K D: The importance of surface area and specific reactivity in the acute pulmonary inflammatory response to particles. Ann Occup Hyg 2002, 46 Suppl I:242-245.

15. Fubini B, Mollo L, Giamello E: Free-radical generation at the solid/liquid interface in iron- containing minerals. Free Radical Research 1995, 23:593-614.

16. Rice TM, Clarke RW, Godleski JJ, Al Mutairi E, Jiang NF, Hauser R, Paulauskis JD: Differential ability of transition metals to induce pulmonary inflammation. Toxicol Appl Pharmacol 200I, | 77:46-53.

17. Squadrito GL, Cueto R, Dellinger B, Pryor WA: Quinoid redox cycling as a mechanism for sustained free radical generation by inhaled airborne particulate matter. Free Radic Biol Med 2001, 3 I: I I32-II38.

18. Morawska L, Zhang JJ: Combustion sources of particles. I. Health relevance and source signatures. Chemosphere 2002, 49:1045-1058.

19. Zhang JJ, Morawska L: Combustion sources of particles: 2. Emission factors and measurement methods. Chemosphere 2002, 49:1059-1074.

20. HEl: Diesel exhaust: a critical analysis of emissions, exposure and health effects.A special report of the Insititute's diesel working group. HEI research report 1995.

21. Tobias HJ, Beving DE, Ziemann PJ, Sakurai H, Zuk M, McMurry PH, Zarling D, Waytulonis R, Kittelson DB: Chemical analysis of diesel engine nanoparticles using a nano-DMA/thermal desorption particle beam mass spectrometer. Environ Sci Technol 2001, 35:2233-2243.
22. DB K: Engines and nanoparticles: a review. J Aerosol Sc 1998, 29:575-588.

23. Heinrich U, Fuhst R, Rittinghausen S, Creutzenberg O, Bellmann B, Koch W, Levsen K: Chronic inhalation exposure of wistar rats and 2 different strains of mice to diesel-engine exhaust, carbon-black, and titanium-dioxide. Inhalation Toxicology 1995, 7:533-556.

24. Workshop ILSI: The relevance of the rat lung response to particle overload for human risk assessment. Inhal Toxicol 2000, I2:.

25. Tran CL, Buchanan D, Cullen RT, Searl A, Jones AD, Donaldson K: Inhalation of poorly soluble particles. II. Influence Of particle surface area on inflammation and clearance. Inhal Toxicol 2000, I 2: I | |3-I|26.

26. Ishihara $\mathrm{Y}, \mathrm{Kagawa} \mathrm{J}$ : Chronic diesel exhaust exposures of rats demonstrate concentration and time-dependent effects on pulmonary inflammation. Inhal Toxicol 2003, I 5:473-492.

27. Mauderly JL, Snipes MB, Barr EB, Belinsky SA, Bond JA, Brooks AL, Chang IY, Cheng YS, Gillett NA, Griffith WC, .: Pulmonary toxicity of inhaled diesel exhaust and carbon black in chronically exposed rats. Part I: Neoplastic and nonneoplastic lung lesions. Res Rep Health Eff Inst 1994: I-75.

28. Miyabara Y, Yanagisawa R, Shimojo N, Takano H, Lim HB, Ichinose T, Sagai $M$ : Murine strain differences in airway inflammation caused by diesel exhaust particles. European Respiratory Journal I998, I I:29I-298.

29. Abe S, Takizawa H, Sugawara I, Kudoh S: Diesel exhaust (DE)induced cytokine expression in human bronchial epithelial cells: a study with a new cell exposure system to freshly generated DE in vitro. Am J Respir Cell Mol Biol 2000, 22:296-303.

30. Bonvallot $\mathrm{V}$, Baeza-Squiban A, Baulig A, Brulant S, Boland S, Muzeau F, Barouki R, Marano F: Organic compounds from diesel exhaust particles elicit a proinflammatory response in human airway epithelial cells and induce cytochrome p450 IAI expression. Am J Respir Cell Mol Biol 200I, 25:5 I5-52I.

31. Henderson RF, Leung HW, Harmsen AG, Mcclellan RO: Species differences in release of arachidonate metabolites in response to inhaled diluted diesel exhaust. Toxicol Lett 1988, 42:325-332.

32. Knaapen AM, Seiler F, Schilderman PA, Nehls P, Bruch J, Schins RP, Borm PJ: Neutrophils cause oxidative DNA damage in alveolar epithelial cells. Free Radic Biol Med 1999, 27:234-240.

33. Parke DV, Parke AL: Chemical-induced inflammation and inflammatory diseases. [Review] [24 refs]. International Journal of Occupational Medicine \& Environmental Health 1996, 9:2 I I-2 I 7.

34. Schins RP: Mechanisms of genotoxicity of particles and fibers. Inhal Toxicol 2002, I4:57-78.

35. Riedl M, az-Sanchez D: Biology of diesel exhaust effects on respiratory function. J Allergy Clin Immunol 2005, I I 5:22 I-228.

36. Baeza-Squiban A, Bonvallot V, Boland S, Marano F: Airborne particles evoke an inflammatory response in human airway epithelium. Activation of transcription factors. Cell Biol Toxicol 1999, I 5:375-380.

37. Ball JC, Straccia AM, Young WC, Aust AE: The formation of reactive oxygen species catalyzed by neutral, aqueous extracts of NIST ambient particulate matter and diesel engine particles. J Air Waste Manag Assoc 2000, 50:1897-1903.

38. Antonini JM: Health effects of welding. Crit Rev Toxicol 2003, 33:61-103.

39. Sferlazza SJ, Beckett WS: The respiratory health of welders. Am Rev Respir Dis 1991, I43: I I34-I I48.

40. Fine JM, Gordon T, Chen LC, Kinney P, Falcone G, Beckett WS: Metal fume fever: characterization of clinical and plasma IL6 responses in controlled human exposures to zinc oxide fume at and below the threshold limit value. J Occup Environ Med 1997, 39:722-726.

4I. Naslund PE, Andreasson S, Bergstrom R, Smith L, Risberg B: Effects of exposure to welding fume: an experimental study in sheep. European Respiratory Journal 1990, 3:800-806.

42. Taylor MD, Roberts JR, Leonard SS, Shi X, Antonini JM: Effects of welding fumes of differing composition and solubility on free radical production and acute lung injury and inflammation in rats. Toxicol Sci 2003, 75:181-191.

43. Li GJ, Zhang LL, Lu L, Wu P, Zheng W: Occupational exposure to welding fume among welders: alterations of manganese, iron, zinc, copper, and lead in body fluids and the oxidative stress status. J Occup Environ Med 2004, 46:24I-248. 
44. Dannenberg EM: Carbon (carbon black). Chapter in 'Encyclopaedia of Chemical Technology', Vol 4 4th Edition, New York, Wiley Interscience 1992:1037-1074.

45. G K: What is carbon black? Degussa 1980.

46. Valberg PA, Watson AY: Lung-cancer rates in carbon-black workers are discordant with predictions from rat bioassay data. Regulatory Toxicology And Pharmacology 1996, 24: I55-170.

47. Gilmour PS, Ziesenis A, Morrison ER, Vickers MA, Drost EM, Ford I, Karg E, Mossa C, Schroeppel A, Ferron GA, Heyder J, Greaves M, MacNee W, Donaldson K: Pulmonary and systemic effects of short-term inhalation exposure to ultrafine carbon black particles. Toxicol Appl Pharmacol 2004, 195:35-44.

48. Shukla A, Timblin C, BeruBe K, Gordon T, McKinney W, Driscoll K, Vacek P, Mossman BT: Inhaled particulate matter causes expression of nuclear factor (NF)- kappaB-related genes and oxidant-dependent NF-kappaB activation in vitro. Am J Respir Cell Mol Biol 2000, 23:182-187.

49. Renwick LC, Donaldson K, Clouter A: Impairment of alveolar macrophage phagocytosis by ultrafine particles. Toxicol Appl Pharmacol 2001, I72:119-127.

50. Gardiner K, van Tongeren M, Harrington M: Respiratory health effects from exposure to carbon black: results of the phase 2 and 3 cross sectional studies in the European carbon black manufacturing industry. Occup Environ Med 200I, 58:496-503.

51. Sorahan T, Hamilton L, van Tongeren M, Gardiner K, Harrington JM: A cohort mortality study of U.K. carbon black workers, 195I-I996. Am J Ind Med 200I, 39:158-170.

52. van Tongeren MJ, Gardiner K, Rossiter CE, Beach J, Harber P, Harrington MJ: Longitudinal analyses of chest radiographs from the European Carbon Black Respiratory Morbidity Study. Eur Respir J 2002, 20:417-425.

53. IARC: IARC monographs on the evaluation of carcinogenic risks to humans. Volume 65 . Printing processes and printing inks, carbon blacks and some nitro compounds. IARC Scientific Publications 1996

54. Borm PJ: Toxicity and occupational health hazards of coal fly ash (CFA). A review of data and comparison to coal mine dust. Ann Occup Hyg 1997, 41:659-676.

55. Ball BR, Smith KR, Veranth JM, Aust AE: Bioavailability of iron from coal fly ash: mechanisms of mobilization and of biological effects. Inhal Toxicol 2000, I 2 Suppl 4:209-225.

56. van Maanen JM, Borm PJ, Knaapen A, van Herwijnen M, Schilderman PA, Smith KR, Aust AE, Tomatis M, Fubini B: In vitro effects of coal fly ashes: hydroxyl radical generation, iron release, and DNA damage and toxicity in rat lung epithelial cells. Inhal Toxicol 1999, II: ||23-||4|

57. Hatch GE, Boykin E, Graham JA, Lewtas J, Pott F, Loud K, Mumford $\mathrm{JL}$ : Inhalable particles and pulmonary host defense: in vivo and in vitro effects of ambient air and combustion particles. Environ Res 1985, 36:67-80.

58. Chen LC, Lam HF, Kim EJ, Guty J, Amdur MO: Pulmonary effects of ultrafine coal fly ash inhaled by guinea pigs. J Toxicol Environ Health 1990, 29:169-184.

59. Tsurudome Y, Hirano T, Yamato H, Tanaka I, Sagai M, Hirano H, Nagata N, Itoh $\mathrm{H}$, Kasai $\mathrm{H}$ : Changes in levels of 8-hydroxyguanine in DNA, its repair and OGGI mRNA in rat lungs after intratracheal administration of diesel exhaust particles. Carcinogenesis 1999, 20:1573-1576.

60. Nordenhall C, Pourazar J, Blomberg A, Levin JO, Sandstrom T, Adelroth E: Airway inflammation following exposure to diesel exhaust: a study of time kinetics using induced sputum [In Process Citation]. Eur Respir J 2000, 15:1046- 105I.

61. Ichinose T, Yajima Y, Nagashima M, Takenoshita S, Nagamachi Y, Sagai M: Lung carcinogenesis and formation of 8-hydroxy-deoxyguanosine in mice by diesel exhaust particles. Carcinogenesis 1997, 18:185-192.

62. Arimoto T, Yoshikawa T, Takano H, Kohno M: Generation of reactive oxygen species and 8-hydroxy-2'-deoxyguanosine formation from diesel exhaust particle components in L 1210 cells. Jpn J Pharmacol 1999, 80:49-54.

63. Ikeda M, Shitashige M, Yamasaki H, Sagai M, Tomita T: Oxidative modification of low density lipoprotein by diesel exhaust particles. Biol Pharm Bull 1995, I 8:866-87I.

64. Li N, Venkatesan MI, Miguel A, Kaplan R, Gujuluva C, Alam J, Nel A: Induction of heme oxygenase-I expression in macrophages by diesel exhaust particle chemicals and quinones via the antioxidant-responsive element. I Immunol 2000, 165:3393-340I.

65. Nel AE, Diaz-Sanchez D, Li N: The role of particulate pollutants in pulmonary inflammation and asthma: evidence for the involvement of organic chemicals and oxidative stress. Curr Opin Pulm Med 2001, 7:20-26.

66. Han JY, Takeshita K, Utsumi H: Noninvasive detection of hydroxyl radical generation in lung by diesel exhaust particles. Free Radic Biol Med 200I, 30:516-525.

67. Marano F, Boland S, Bonvallot V, Baulig A, Baeza-Squiban A: Human airway epithelial cells in culture for studying the molecular mechanisms of the inflammatory response triggered by diesel exhaust particles. Cell Biol Toxicol 2002, 18:315-320.

68. Hiura TS, Kaszubowski MP, Li N, Nel AE: Chemicals in diesel exhaust particles generate reactive oxygen radicals and induce apoptosis in macrophages. I Immunol 1999, 163:5582-5591.

69. Hashimoto S, Gon Y, Takeshita I, Matsumoto K, Jibiki I, Takizawa H, Kudoh S, Horie T: Diesel exhaust particles activate p38 MAP kinase to produce interleukin 8 and RANTES by human bronchial epithelial cells and $\mathbf{N}$-acetylcysteine attenuates p38 MAP kinase activation. Am J Respir Crit Care Med 2000, 161:280-285.

70. Takizawa H, Ohtoshi T, Kawasaki S, Kohyama T, Desaki M, Kasama T, Kobayashi K, Nakahara K, Yamamoto K, Matsushima K, Kudoh S: Diesel exhaust particles induce NF-kappa B activation in human bronchial epithelial cells in vitro: importance in cytokine transcription. J Immunol 1999, 162:4705-47 I I.

7I. Terada N, Hamano N, Maesako KI, Hiruma K, Hohki G, Suzuki K, Ishikawa K, Konno A: Diesel exhaust particulates upregulate histamine receptor mRNA and increase histamine-induced IL-8 and GM-CSF production in nasal epithelial cells and endothelial cells [see comments]. Clin Exp Allergy 1999, 29:52-59.

72. Salvi SS, Nordenhall C, Blomberg A, Rudell B, Pourazar J, Kelly FJ, Wilson S, Sandstrom T, Holgate ST, Frew AJ: Acute exposure to diesel exhaust increases IL-8 and GRO-alpha production in healthy human airways. Am J Respir Crit Care Med 2000, 161:550-557.

73. Yang HM, Ma JC, Castranova V, Ma JH: Effects of diesel exhaust particles on the release of interleukin-I and tumor necrosis factor-alpha from rat alveolar macrophages. Experimental Lung Research 1997, 23:269-284.

74. Steerenberg PA, Zonnenberg JAJ, Dormans JAMA, Joon PT, Wouters IM, vanBree L, Scheepers PT], VanLoveren H: Diesel exhaust particles induced release of interleukin 6 and 8 by (primed) human bronchial epithelial cells (BEAS 2B) in vitro. Experimental Lung Research 1998, 24:85-100.

75. Salvi SS, Nordenhall C, Blomberg A, Rudell B, Pourazar J, Kelly FJ, Wilson S, Sandstrom T, Holgate ST, Frew A]: Acute Exposure to Diesel Exhaust Increases IL-8 and GRO-alpha Production in Healthy Human Airways. Am J Respir Crit Care Med 2000, 16 1:550-557.

76. Driscoll KE: Role of inflammation in the development of rat lung tumors in response to chronic particle exposure. Inhalation Toxicology 1996, 8 suppl: | 39-I53.

77. Brown DM, Stone V, Findlay P, MacNee W, Donaldson K: Increased inflammation and intracellular calcium caused by ultrafine carbon black is independent of transition metals or other soluble components [In Process Citation]. Occup Environ Med 2000, 57:685-691.

78. Wilson MR, Lightbody JH, Donaldson K, Sales J, Stone V: Interactions between ultrafine particles and transition metals in vivo and in vitro. Toxicol Appl Pharmacol 2002, 184:172-179.

79. Dick CA, Brown DM, Donaldson K, Stone V: The role of free radicals in the toxic and inflammatory effects of four different ultrafine particle types. Inhal Toxicol 2003, 1 5:39-52.

80. V S, Shaw J, DM B, MacNee W, SP F, K D: The role of oxidative stress in the prolonged inhibitory effect of ultrafine carbon black on epithelial cell function. Toxicol In Vitro 1998, I 2:649-659.

8I. Stone V, Tuinman M, Vamvakopoulos JE, Shaw J, Brown D, Petterson S, Faux SP, Borm P, MacNee W, Michaelangeli F, Donaldson K: Increased calcium influx in a monocytic cell line on exposure to ultrafine carbon black. Eur Respir J 2000, 15:297-303.

82. Ermak G, Davies KJ: Calcium and oxidative stress: from cell signaling to cell death. Mol Immunol 2002, 38:7I3-72I. 
83. Brown DM, Donaldson K, Borm PJ, Schins RP, Dehnhardt M, Gilmour $P$, Jimenez LA, Stone V: Calcium and ROS-mediated activation of transcription factors and TNF-alpha cytokine gene expression in macrophages exposed to ultrafine particles. Am J Physiol Lung Cell Mol Physiol 2004, 286:L344-L353.

84. Tamaoki J, Isono K, Takeyama K, Tagaya E, Nakata J, Nagai A: Ultrafine carbon black particles stimulate proliferation of human airway epithelium via EGF receptor-mediated signaling pathway. Am J Physiol Lung Cell Mol Physiol 2004.

85. Blanc $\mathrm{P}$, Wong $\mathrm{H}$, Bernstein MS, Boushey HA: An experimental human model of metal fume fever. Annals of Internal Medicine 1991, I 1 4:930-936.

86. Blanc PD, Boushey HA, Wong H, Wintermeyer SF, Bernstein MS: Cytokines in metal fume fever. American Review Of Respiratory Disease 1993, 147:134-138.

87. Kuschner WG, D'Alessandro A, Wintermeyer SF, Wong H, Boushey HA, Blanc PD: Pulmonary responses to purified zinc oxide fume. J Investig Med 1995, 43:37I-378.

88. Antonini JM, Krishna Murthy GG, Rogers RA, Albert R, Ulrich GD, Brain, JD.: Pneumotoxicity and pulmonary clearance of different welding fumes after intratracheal instillation in the rat. Toxicology \& Applied Pharmacology 1996, I40: 188-199.

89. Lam HF, Chen LC, Ainsworth D, Peoples S, Amdur MO: Pulmonary function of guinea pigs exposed to freshly generated ultrafine zinc oxide with and without spike concentrations. Am Ind Hyg Assoc J 1988, 49:333-34I.

90. McNeilly JD, Jimenez LA, Clay MF, W MN, Howe A, Heal MR, Beverland IJ, K D: Soluble transition metals in welding fumes cause inflammation via activation of NF-B and AP-I. Toxicol Lett 2005, (in press):

91. Smith KR, Veranth JM, Hu AA, Lighty JS, Aust AE: Interleukin-8 levels in human lung epithelial cells are increased in response to coal fly ash and vary with the bioavailability of iron, as a function of particle size and source of coal. Chem Res Toxicol 2000, 13:118-125.

92. Chen Y, Shah N, Huggins FE, Huffman GP: Transmission electron microscopy investigation of ultrafine coal fly ash particles I. Environ Sci Technol 2005, 39: I I44-I I 5 I.

93. Goldberg MS, Bailar JCIII, Burnett RT, Brook JR, Tamblyn R, Bonvalot Y, Ernst P, Flegel KM, Singh RK, Valois MF: Identifying subgroups of the general population that may be susceptible to shortterm increases in particulate air pollution: a time-series study in Montreal, Quebec. Res Rep Health Eff Inst 2000:7-II 3

94. Schwartz J, Dockery DW: Increased mortality in Philadelphia associated with daily air pollution concentrations. American Review Of Respiratory Disease 1992, 145:600-604.

95. Clancy L, Goodman P, Sinclair H, Dockery DW: Effect of air-pollution control on death rates in Dublin, Ireland: an intervention study. Lancet 2002, 360:1210-1214.

96. Dockery DW, Pope CA, Xu XP, Spengler JD, Ware JH, Fay ME, Ferris BG, Speizer FE: An association between air-pollution and mortality in 6 united-states cities. New England Journal Of Medicine 1993, 329:1753-1759.

97. Peters A, Dockery DW, Muller JE, Mittleman MA: Increased particulate air pollution and the triggering of myocardial infarction. Circulation 200I, 103:2810-28I5.

98. Peters A, von KS, Heier M, Trentinaglia I, Hormann A, Wichmann HE, Lowel $\mathrm{H}$ : Exposure to traffic and the onset of myocardial infarction. N Engl J Med 2004, 35 I: I72I- I730.

99. Peters A, Perz S, Doring A, Stieber J, Koenig W, Wichmann HE: Increases in heart rate during an air pollution episode. $\mathrm{Am} J$ Epidemiol 1999, 150:1094-1098.

100. Devlin RB, Ghio AJ, Kehrl H, Sanders G, Cascio W: Elderly humans exposed to concentrated air pollution particles have decreased heart rate variability. Eur Respir J Suppl 2003, 40:76s-80s.

I0I. Brook RD, Brook JR, Urch B, Vincent R, Rajagopalan S, Silverman F: Inhalation of fine particulate air pollution and ozone causes acute arterial vasoconstriction in healthy adults. Circulation 2002, 105:1534-1536.

102. Suadicani P, Hein HO, Gyntelberg F: Airborne occupational exposure, $A B O$ phenotype and risk of ischaemic heart disease in the Copenhagen Male Study. J Cardiovasc Risk 2002, 9:191-198.

103. Brook RD, Franklin B, Cascio W, Hong Y, Howard G, Lipsett M, Luepker R, Mittleman M, Samet J, Smith SC], Tager I: Air pollution and cardiovascular disease: a statement for healthcare pro- fessionals from the Expert Panel on Population and Prevention Science of the American Heart Association. Circulation 2004, 109:2655-267।.

104. Routledge HC, Ayres JG, Townend JN: Why cardiologists should be interested in air pollution. Heart 2003, 89: I383-I 388.

105. Nemmar A, Hoet PH, Vanquickenborne B, Dinsdale D, Thomeer M, Hoylaerts MF, Vanbilloen H, Mortelmans L, Nemery B: Passage of inhaled particles into the blood circulation in humans. Circulation 2002, 105:4II-4II4.

106. Nemmar A, Vanbilloen H, Hoylaerts MF, Hoet PH, Verbruggen A, Nemery $B$ : Passage of intratracheally instilled ultrafine particles from the lung into the systemic circulation in hamster. Am J Respir Crit Care Med 200I, 164: 1665-1668.

107. Nemmar A, Hoylaerts MF, Hoet PH, Nemery B: Possible mechanisms of the cardiovascular effects of inhaled particles: systemic translocation and prothrombotic effects. Toxicol Lett 2004, I 149:243-253.

108. W K, M S, F E, P M, Takenaka S, Oberdorster G, A Z: Minute translocation of inhlaed ultrafine insoluble iridium particles from lung epithelium to extrapulmonary tissues. Ann Occup Hyg 2002, 46 SuppI I:223-226.

109. Kreyling WG, Semmler M, Erbe F, Mayer P, Takenaka S, Schulz H, Oberdorster G, Ziesenis A: Translocation of ultrafine insoluble iridium particles from lung epithelium to extrapulmonary organs is size dependent but very low. J Toxicol Environ Health $A$ 2002, 65:1513-1530.

1 I0. Oberdorster G, Z S, V A, AP E, Gelein R, AK L, W K, Cox C: Extrapulmonary transocation of ultrafine carbon particles following inhalation exposure. 2002

III. Oberdorster G, Z S, AP E, Gelein R, W K, Cox C: Translocation of inhaled ultrafine particles to the brain. Inhal Toxicol 2004, 16:437-445.

II2. Yu IJ, Park JD, Park ES, Song KS, Han KT, Han JH, Chung YH, Choi $\mathrm{BS}$, Chung $\mathrm{KH}$, Cho $\mathrm{MH}$ : Manganese distribution in brains of Sprague-Dawley rats after $\mathbf{6 0}$ days of stainless steel weldingfume exposure. Neurotoxicology 2003, 24:777-785.

113. Erikson KM, Dorman DC, Lash LH, Dobson AW, Aschner M: Airborne manganese exposure differentially affects end points of oxidative stress in an age- and sex-dependent manner. Biol Trace Elem Res 2004, 100:49-62.

1 14. Normandin L, Carrier G, Gardiner PF, Kennedy G, Hazell AS, Mergler D, Butterworth RF, Philippe S, Zayed J: Assessment of bioaccumulation, neuropathology, and neurobehavior following subchronic (90 days) inhalation in Sprague-Dawley rats exposed to manganese phosphate. Toxicol Appl Pharmacol 2002, 183:135-145.

115. Racette BA, McGee-Minnich L, Moerlein SM, Mink JW, Videen TO, Perlmutter JS: Welding-related parkinsonism: clinical features, treatment, and pathophysiology. Neurology 200I, 56:8-13.

1 16. Sadek AH, Rauch R, Schulz PE: Parkinsonism due to manganism in a welder. Int I Toxicol 2003, 22:393-40I.

117. Dorman DC, Struve MF, James RA, Marshall MW, Parkinson CU, Wong BA: Influence of particle solubility on the delivery of inhaled manganese to the rat brain: manganese sulfate and manganese tetroxide pharmacokinetics following repeated (I 4-day) exposure. Toxicol Appl Pharmacol 200I, I70:79-87.

II8. Stuart AE: The reticulo-endothelial system. $E$ and $S$ Livingstone, Edinburgh 1970

119. LeFevre ME, Green FH, Joel DD, Laqueur W: Frequency of black pigment in livers and spleens of coal workers: correlation with pulmonary pathology and occupational information. Hum Pathol 1982, 13:1 121-1126.

120. Pope CAll: Particulate air pollution, C-reactive protein, and cardiac risk. Eur Heart / 200I, 22: I |49-1 I 50.

12I. Baumann H, Gauldie J: The acute phase response [see comments]. Immunol Today 1994, I 5:74-80.

122. Khandoga A, Stampfl A, Takenaka S, Schulz H, Radykewicz R, Kreyling $W$, Krombach F: Ultrafine particles exert prothrombotic but not inflammatory effects on the hepatic microcirculation in healthy mice in vivo. Circulation 2004, 109:1320-1325

123. Takano H, Yoshikawa T, Ichinose T, Miyabara Y, Imaoka K, Sagai M: Diesel exhaust particles enhance antigen-induced airway inflammation and local cytokine expression in mice. $\mathrm{Am} J$ Respir Crit Care Med 1997, 1 56:36-42. 
124. Knaapen AM, Borm PJ, Albrecht C, Schins RP: Inhaled particles and lung cancer. Part A: Mechanisms. Int J Cancer 2004, 1 09:799-809.

125. Iwai K, Adachi S, Takahashi M, Moller L, Udagawa T, Mizuno S, Sugawara I: Early oxidative DNA damages and late development of lung cancer in diesel exhaust-exposed rats. Environ Res 2000, 84:255-264

126. Dasenbrock C, Peters L, Creutzenberg O, Heinrich U: The carcinogenic potency of carbon particles with and without PAH after repeated intratracheal administration in the rat. Toxicology Letters 1996, 88:15-21.

127. Godschalk RW, Moonen EJ, Schilderman PA, Broekmans WM, Kleinjans JC, Van Schooten FJ: Exposure-route-dependent DNA adduct formation by polycyclic aromatic hydrocarbons. Carcinogenesis 2000, $21: 87-92$.

128. Nikula KJ, Snipes MB, Barr EB, Griffith WC, Henderson RF, Mauderly $\mathrm{JL}$ : Comparative pulmonary toxicities and carcinogenicities of chronically inhaled diesel exhaust and carbon-black in f344 rats. Fundamental And Applied Toxicology 1995, 25:80-94.

129. Maeng SH, Chung HW, Yu IJ, Kim HY, Lim CH, Kim KJ, Kim SJ, Ootsuyama $\mathrm{Y}$, Kasai $\mathrm{H}$ : Changes of 8-OH-dG levels in DNA and its base excision repair activity in rat lungs after inhalation exposure to hexavalent chromium. Mutat Res 2003, 539:109-116.

I30. Yu IJ, Song KS, Maeng SH, Kim SJ, Sung JH, Han JH, Chung YH, Cho $\mathrm{MH}$, Chung $\mathrm{KH}$, Han KT, Hyun JS, Kim KJ: Inflammatory and genotoxic responses during 30-day welding-fume exposure period I. Toxicol Lett 2004, I 54: I05-I I5.

I3I. van Maanen JM, Borm PJ, Knaapen A, van Herwijnen M, Schilderman $P A$, Smith KR, Aust AE, Tomatis M, Fubini B: In vitro effects of coal fly ashes: hydroxyl radical generation, iron release, and DNA damage and toxicity in rat lung epithelial cells [In Process Citation]. Inhal Toxicol 1999, I I: I I23-I| 4 I.

132. Prahalad AK, Inmon J, Dailey LA, Madden MC, Ghio AJ, Gallagher JE. Air pollution particles mediated oxidative DNA base damage in a cell free system and in human airway epithelial cells in relation to particulate metal content and bioreactivity. Chem Res Toxicol 200I, I 4:879-887.

133. Kleinjans JC, Janssen YM, van Agen B, Hageman GJ, Schreurs JG: Genotoxicity of coal fly ash, assessed in vitro in Salmonella typhimurium and human lymphocytes, and in vivo in an occupationally exposed population. Mutat Res 1989, 224: I27-I34.

134. Brook RD, Brook JR, Rajagopalan S: Air pollution: the "Heart" of the problem. Curr Hypertens Rep 2003, 5:32-39.

\section{Publish with Biomed Central and every scientist can read your work free of charge}

"BioMed Central will be the most significant development for disseminating the results of biomedical research in our lifetime. "

Sir Paul Nurse, Cancer Research UK

Your research papers will be:

- available free of charge to the entire biomedical community

- peer reviewed and published immediately upon acceptance

- cited in PubMed and archived on PubMed Central

- yours - you keep the copyright
BioMedcentral 